\title{
The Effects of Bilateral Tax Treaties on U.S. FDI Activity
}

\author{
Bruce A. Blonigen \\ (University of Oregon and NBER)
}

Department of Economics

1285 University of Oregon

Eugene, OR 97403-1285

Ph: 541-346-4680

Email: bruceb@oregon.uoregon.edu

\author{
Ronald B. Davies \\ (University of Oregon)
}

Department of Economics
1285 University of Oregon
Eugene, OR 97403-1285
Ph: 541-346-4671
Email: rdavies@oregon.uoregon.edu

\begin{abstract}
The effects of bilateral tax treaties on FDI activity have been unexplored, despite significant ongoing activities by countries to negotiate and ratify these treaties. This paper estimates the impact of bilateral tax treaties using both U.S. inbound and outbound FDI over the period 1966-1992. Robust to a wide variety of alternative specifications, we find no evidence that bilateral tax treaties increase FDI activity, contrary to OECD-stated goals for such treaties. In fact, our estimates suggest that for our sample there may instead be economically and statistically significant negative effects of new bilateral tax treaties on U.S. outbound activity to the tax treaty partner country. These findings are consistent with claims that tax treaties are not intended to improve capital flows, but rather to reduce tax evasion through transfer pricing practices or otherwise.
\end{abstract}

JEL Classification: F21, F23, H25.

Key words: Foreign direct investment, tax treaties, multinational corporations.

*This paper has benefitted greatly from comments received by Reuven Avi-Yonah, Andrew Bernard, Ann Harrison, Stephen Haynes, Keith Head, Robert Lipsey, James Markusen, William Randolph, and seminar participants the 2000 Empirical Investigations in International Trade conference, the National Bureau of Economic Research, the Fall 2000 National Tax Association meetings, the Summer 2000 Western Economic Association meetings and the Winter 2001 International Economic and Finance Society meetings. Blonigen acknowledges financial support from a Richard A. Bray Fellowship. Any errors or omissions are the responsibility of the authors. 


\section{Introduction}

Empirical studies on the effects of taxation on foreign direct investment (FDI) are as numerous and varied as the tax policies they study. Until this point, however, the impacts of bilateral tax treaties governing the taxation of FDI activity have been unexplored. ${ }^{1}$ Worldwide, there exists a network of over 2,000 treaties which affect the taxation of the large majority of FDI (Radaelli, 1997). According to the Bureau of Economic Analysis (BEA, 1998), by 1998 these treaties covered approximately $\$ 774$ billion of U.S. investment abroad (outbound FDI) and \$586 billion of foreign investment within the U.S. (inbound FDI). These amounts represented $78 \%$ of total U.S. outbound FDI and $96 \%$ of the total U.S. inbound FDI.

The introduction to the OECD's model tax treaty states that a primary goal of a tax treaty is "removing the obstacles that double taxation presents", thus reducing its "harmful effects on the exchange of goods and services and movements of capital, technology, and persons" (OECD, 1997, p. I-1). Thus, on the surface bilateral tax treaties appear designed to encourage FDI by lowering withholding taxes on reparations to treaty partners and harmonizing tax laws. Research by Altshuler and Newlon (1991), Hines (1992), Altshuler, Newlon, and Randolph (1995), and Mutti and Grubert (1996) indicates that changes in withholding taxes can affect both the timing of repatriation decisions and the mode of repatriation by firms. While this indicates that these treaties can affect profitability of existing foreign investors, it does not necessarily say anything about the effects of these changes on overall FDI activity.

Furthermore, there are several legal and economic arguments suggesting that treaties will have no effect on FDI activity. Dagan (2000) asserts that double taxation can be alleviated unilaterally just as well as through a bilateral agreement, and that the actual intent of treaties is to reduce administration

${ }^{1}$ Hines and Willard (1992) empirically examined the number of treaties a country signs as well as the tax concessions dictated by a particular treaty. However, they do not include the amount of FDI activity as an explanatory variable nor do they consider the effect of taxation on FDI. The United Nations (1998) has studied the effects of bilateral treaties for the promotion and protection of FDI. These treaties are generally geared towards increasing investment in developing nations by ensuring a favorable political and economic climate and do not address tax concerns. 
costs, reduce tax evasion, and to extract tax concessions from host countries. In fact, Dagan goes so far as to condemn the double taxation objective as "a myth" (p. 939). Radaelli (1997) also asserts that U.S. tax treaties are primarily geared towards reducing tax evasion rather than promoting FDI. In addition to this concern is the possibility that these treaties stem primarily from rent-seeking lobbying efforts by current foreign investors, rather than from a desire by governments to reduce distortions and enhance efficiency. ${ }^{2}$ Finally, it is not clear that reducing firm's withholding tax burdens would necessarily impact the amount of investment. Hartman (1985) and Sinn (1993) point out that, since withholding taxes are only paid upon repatriation, it is less expensive to expand an overseas affiliate through retained earnings than through repatriated and re-exported funds. Because of this, they contend that only mature, non-expanding foreign affiliates will repatriate earnings. As a result, they predict that withholding taxes may have no effect on the size of FDI activity.

These varied arguments indicate that the effect of bilateral tax treaties on the amount of FDI between the U.S. and partner countries is an open question. The answer is of particular importance in light of the efforts expended by the U.S. Treasury to negotiate the treaties, as well as the necessary ratification by the U.S. Senate. This paper makes a first attempt at answering this question by estimating the impact of bilateral tax treaties on both U.S. inbound and U.S. outbound FDI over the period from 1966 to 1992 . The sample we construct represents easily the most comprehensive set of consistent data on FDI used in the literature to date and allows us to examine the impact of new bilateral tax treaties for a wide variety of U.S. partner countries that occurred during the 1970 s and 1980 s. $^{3}$ We explore tax treaty effects on two measures of overall FDI activity: sales by foreign affiliates and FDI stocks. Our empirical framework for testing the determinants of FDI activity is one recently developed by Carr, Markusen and

\footnotetext{
${ }^{2}$ Radaelli (1997) argues that, at least for the U.S., treaty formation is well-insulated from the interests of business groups.

${ }^{3}$ Unfortunately, the time frame of the data preclude us from credibly estimating the impact of tax treaties with the U.S.'s largest FDI partners, as these treaties began in the decade after WWII and before our sample begins.
} 
Maskus (2001) and Markusen and Maskus (1999a,1999b). As opposed to the traditional gravity model which is driven by the data, this framework is more strongly based on the established theory of multinational enterprises.

Robust to a wide variety of alternative specifications, we find no evidence that bilateral tax treaties increase FDI activity, contrary to OECD-stated goals for such treaties. In fact, for certain specifications, our estimates suggest that for our sample there may be economically and statistically significant negative effects of new bilateral tax treaties on U.S. outbound activity to the tax treaty partner country. This suggests that, rather than opening the floodgates for new FDI, treaties may reduce the incentive for some firms to engage in FDI, possibly due to the elimination of opportunities for transfer pricing and tax evasion. We further find that this negative effect on outbound FDI activity occurs as a one-time drop in the growth of FDI activity in the treaty year with no significant ramifications in subsequent years, and that this negative effect is fairly consistent across the countries that negotiated bilateral tax treaties with the U.S. during the period of our sample. Thus, at best, our results find no support for the idea the tax treaties increase FDI and that they may instead have much the opposite effect.

The paper proceeds as follows. In Section II, we discuss U.S. tax treaties including their history, how they are formed, and their key functions. In Section III, we present our empirical methodology and data. Section IV presents our results and section V concludes.

\section{Tax Treaties}

In this section, we briefly discuss the history and functions of bilateral tax treaties. Given our paper's focus, this section concentrates on these issues from a U.S. perspective; however, most of the discussion applies to other countries as well. The process of creating an international tax treaty with the U.S. is the same as for other international treaties. The Assistant Secretary for Tax Policy and the International Tax Counsel, acting on behalf of the Department of the Treasury, undertake the actual treaty 
negotiation. After the treaty is signed by the President or his delegate, it proceeds to the Senate. There, the Senate Foreign Relations Committee holds hearings before the treaty proceeds to the full Senate for ratification. ${ }^{4}$ Not all signed treaties receive Senate approval. For example the Bangladeshi treaty was signed in 1981 but failed in the Senate. Some treaties fail multiple times before they are finally ratified. ${ }^{5}$ Once ratified, treaties usually remain in effect, although most contain provisions for termination after a six-month notification by either nation (Doernberg, 1997). Of those treaties allowed to lapse, the majority (Aruba, Malta, and the Netherlands-Antilles) were the result of insufficient attempts by partner nations to prevent treaty shopping, a practice in which investments are funneled through a treaty country by a third nation for the purpose of avoiding or reducing taxes. ${ }^{6}$ As with many types of international agreements, the number of tax treaties the U.S. has in force is on the rise. Table 1, which lists U.S. treaty partners, shows that the U.S. has gone through three major waves of treaty negotiations. The first followed WWII and saw the U.S. complete treaties with its major economic partners: the western European countries, Canada, Japan, Australia, and New Zealand. The second wave of the late 70's and early 80 's focused on a wider variety of countries, including China, Egypt, Korea, India, Indonesia, the Phillippines, and Spain. More recently, beginning in the early 1990's, the fall of the former Soviet Union has led to additional U.S. treaty activity with respect to many of the former Soviet Bloc countries.

${ }^{4}$ Since tax treaties are federal instruments, they supercede state or local laws. Generally, the only limitation U.S. tax treaties place on state taxation is that a foreign corporation must be treated the same as a firm incorporated in another state (White, 1991).

${ }^{5}$ The original draft of the U.S./Cyprus treaty was signed in 1981 but did not pass the Senate. An amended version also failed in 1985. In 1987, a final version of the treaty was signed but was not ratified until 1988.

${ }^{6}$ The treaty with South Africa was terminated as part of the Comprehensive Anti-Apartheid Act of 1987. It was reinstated in 1997. The U.S./U.S.S.R. treaty, which was officially terminated in 1992, has been extended to cover former Soviet block countries until individual treaties can be negotiated. The only terminated treaty which was not canceled by the U.S. was that with Honduras. This treaty eliminated withholding taxes on FDI by both countries. Due to the almost entirely one-way nature of FDI flows, Honduras felt that all gains from the treaty were accruing to the U.S. and terminated it in 1967 (Diamond and Diamond, 1998). 
Overall, the pace of new treaty implementation has increased. In fact, half of the treaties currently in force were ratified only in the past twenty years with over $20 \%$ of the current treaties implemented during the 1990 's alone.

Tax treaties perform four primary functions. The first is to standardize tax definitions and solidify the tax jurisdictions of treaty partners. It is common practice that only income generated by foreigners through a permanent establishment in the host country is subject to host taxation. If the countries differ in their definitions of permanent establishments, this can lead to double taxation and inefficient capital flows (Hamada, 1966). The impact of differing tax definitions on FDI is explored theoretically by Janeba (1996). Hines (1988) finds that the 1986 Tax Reform Act, which revised U.S. definitions, had a significant effect on U.S. multinationals (MNEs). Since a common goal for tax treaties is to reduce double taxation and the inefficiencies it causes, standardization of tax definitions and jurisdictions is a powerful tool. Treaty tax definitions generally match those provided by the OECD's model tax treaty $(\mathrm{OECD}, 1997)$. A second role for a tax treaty is to promote the exchange of tax information. This improves a treaty partner's ability to enforce its enforcing tax laws. This provision is particularly relevant for multinational corporations due to their ability to engage in transfer pricing to avoid taxation. ${ }^{7}$ The third goal of tax treaties, especially recent treaties, is to prevent treaty shopping. According to Radaelli (1997), concerns over treaty shopping have prompted the U.S. to renegotiate many of its older treaties as well. Although there are many variations in the regulations regarding treaty shopping, the most common rules restrict treaty benefits if more than $50 \%$ of a corporation's stock is held by a third, non-treaty country's residents (Doernberg, 1997).

Finally, tax treaties affect the actual taxation of multinationals. They do so through the rules affecting double taxation relief and the withholding taxes levied on repatriations by FDI. Following the

${ }^{7}$ The U.S. has also entered into tax information exchange agreements with countries which are not tax treaty partners. Additionally, the U.S. has ratified the multilateral OECD Convention on Mutual Assistance in Tax Matters which provides for information exchange (OECD, 1989). 
OECD model treaty guidelines, tax treaties with the U.S. specify that both countries must offer either foreign tax credits when calculating the domestic tax bill or exempt foreign-earned profits from domestic taxation. ${ }^{8}$ This does not usually affect U.S. tax policy as it already provides foreign tax credits to its investors whether their income is earned in a treaty or a non-treaty country. It does, however, affect the taxation of some treaty partners. ${ }^{9}$ In addition to the provisions for double taxation relief, the treaties also often reduce maximum allowable withholding taxes on three types of remitted income: dividend payments, interest payments, and royalty payments. There are no tax treaties which raise tax rates.

From the above discussion, the primary costs and benefits of entering into a tax treaty can be summarized as follows. Since a treaty can lower the overseas taxes, more income is repatriated to the home nation. At the same time, lower overseas tax rates can promote a more efficient global allocation of investment. ${ }^{10}$ This gain is accompanied by potentially reduced tax receipts since treaties also lower the tax rates levied on inbound investment. This cost can be mitigated in two ways. First, improved information exchange may reduce tax evasion. It can also reduce the administrative costs associated with enforcement and tax collection. Second, since withholding taxes can be tailored to the specific investment from a treaty partner, it may be possible to set tax rates which encourage tax-sensitive inbound

${ }^{8}$ Under a tax credit, the domestic tax bill is calculated by applying the standard domestic tax rate to the pre-foreign tax level of overseas profits. A credit against this amount is then applied up to the amount of the foreign taxes paid. If this credit exceeds the domestic tax liability, the firm is in an "excess credit" position and pays no additional taxes on these overseas profits. If the home tax bill is greater than the amount of the credit, the firm is in an "excess limit" position and pays the remaining amount to the home government.

${ }^{9}$ For instance, Belgium applies a reduced domestic tax rate to the foreign-earned profits of its residents. Under the U.S./Belgium treaty, however, income earned by Belgian firms in the U.S. is exempt from Belgian taxation.

${ }^{10}$ Note that a lower foreign tax rate does not guarantee a reduction in the firm's total tax bill. As noted by Altshuler and Newlon (1991), only firms in excess credit will benefit from this change. Thus, a decrease in the overseas tax rate may not improve capital flows. Also, as discussed by Ramaswami (1968) and Bond and Samuelson (1989), this effect may be to the detriment of the home country due to foreign factor market effects. 
investment and actually raise total tax receipts. ${ }^{11}$ Finally, a tax treaty, regardless of its specific terms, can promote investment by reducing uncertainty about the overseas tax environment. Since a treaty can signal a willingness for governments to work out differences, this may boost investor confidence which leads to increased willingness to export capital.

These treaty provisions, however, can cut both ways and may instead reduce the incentive to engage in FDI. If firms maximize after-tax profits, some of them may choose to operate in multiple countries in an effort to reduce their taxes. For example, it is well known that multinational firms can minimize their tax burden through transfer pricing. ${ }^{12}$ By manipulating the price of goods traded between their various subsidiaries, firms can shift profits to low tax locations. This provides an incentive to invest in those low tax locations in order to shield profits from taxes. This was the argument put forth by Casson (1979). A treaty which reduces the ability to transfer price also reduces the incentive to invest for tax minimization reasons. Additionally, because treaties streamline the tax environment and encourage the exchange of tax information, a treaty may make it easier for governments to reduce other types of tax evasion, such as misrepresentation. Therefore, to the extent that some firms engage in FDI simply to minimize taxes, tax treaties may reduce FDI activity, not increase it. Thus, the effects of tax treaties on FDI activity is an open question, and we next turn to the data to estimate these effects for U.S. FDI activity.

\section{Empirical Methodology and Data}

\section{A. Empirical Methodology}

${ }^{11}$ As derived in Bond and Samuelson (1989) among others, the tax revenue maximizing tax rate on inbound FDI is $1 /(1+$,$) , where, is the elasticity of inbound FDI supply. If, varies across countries,$ the revenue maximizing tax rate will differ across countries. Since a treaty allows a country to lower its tax rate, this can actually raise tax revenues if the current tax rate is greater than the optimal tax on FDI from that particular country.

${ }^{12}$ For an explanation of transfer pricing, see Caves (1993). Graham and Krugman (1995) provides examples of firms recently prosecuted for transfer pricing by the U.S. 
To estimate the effect of U.S. bilateral tax treaties, we need an empirical model of MNE/FDI activity that reasonably captures the effect of other factors. While variations of a gravity model have arguably been the most popular empirical framework for examining FDI activity across countries, it lacks connection to a recognized formal theory of MNE activity. In contrast, recent papers by Carr, Markusen, and Maskus (2001) and Markusen and Maskus (1999a, 1999b) establish empirical models of FDI activity that are arguably more grounded in the formal theories of MNE activity that have been developed in the past fifteen years. In particular, Markusen and Maskus provide an "unrestricted" empirical model of MNE/FDI activity that nests a number of alternative theories of MNE activity. The theories nested in their empirical framework include horizontal MNE models, vertical MNE models, and the knowledgecapital MNE model which integrates the horizontal and vertical MNE models. Markusen and Maskus (1999b) use their empirical model to examine affiliate sales of U.S. firms in other countries and foreign affiliate sales in the U.S. over the period 1986-1994. Their unrestricted specification fits their data quite well and, in general, finds support for the horizontal MNE theoretical model. The Markusen and Maskus (or M-M) empirical model is specified by the following equation:

$$
\text { FDI }_{\mathrm{ij}}=f\left(\operatorname{SUMGDP}_{\mathrm{ij}}, \operatorname{GDPDIFSQ}_{\mathrm{ij}}, \mathrm{D} \operatorname{SKDGDPD}_{\mathrm{ij}}, \mathrm{D} \operatorname{SKDSUMG}_{\mathrm{ij}}, \mathrm{D} \operatorname{SKDSUMG}_{\mathrm{ij}}, \operatorname{DIST}_{\mathrm{ij}}, \mathrm{Z}_{\mathrm{ij}}\right)
$$

The first five independent variables on the right hand side of equation (1) are the variables specific to the M-M framework. The first two terms are relatively straightforward, with SUMGDP defined as the sum of the two countries' real GDPs, and GDPDIFSQ defined as the squared difference between the two countries' real GDP. If horizontal MNEs are responsible for most FDI activity, then there is an expected positive correlation between SUMGDP and FDI activity and an expected negative correlation between GDPDIFSQ and FDI activity. The intuition is that with some positive level of trade frictions, larger and more similar sized markets better support the higher fixed costs associated with setting up production across countries (versus exporting) and lead to greater MNE activity. 
The third, fourth and fifth terms on the right-hand side of equation (1) are more complicated interaction terms. D2SKDGDPD is an interaction term between three variables; D2, SKD, and GDPD. D2 is a dummy variable that takes the value of " 1 " if the parent country for MNE activity is relatively skilled-labor abundant to the host country, SKD is the difference in relative skilled-labor abundance between the two countries, and GDPD is the real GDP difference between the two countries. ${ }^{13}$ Markusen and Maskus (1999b) argue that this coefficient will have a negative sign if the knowledge capital model is an accurate picture of MNE activity, and will be insignificant if the other alternative MNE models (horizontal and vertical) are more realistic. D2SKDSUMG is another interaction term that is perhaps the most important variable distinguishing between the alternative MNE models. This variable interacts D2 and SKD (as defined above) with SUMGDP. This variable is hypothesized to have a positive sign if the vertical or knowledge capital MNE models fit the data, but a negative sign if the horizontal MNE model is a better fit. The main intuition behind these differences is that greater skill differences generate greater MNE activity in the vertical model. In contrast, greater skill differences negatively impact horizontal MNE formation as the cost of skilled labor goes up in the skilled labor country from increasing differences, making it more difficult to compete against national firms in the skilled-labor scarce country. The knowledge capital model has aspects of the vertical model that means skill differences can positively affect MNE activity as well. Finally, D1SKDSUMG identifies the symmetrically opposite effects of D2SKDSUMG for the situation when the parent country is relatively skilled-labor scarce. It does this by interacting a dummy variable that takes the value of "-1" when the parent is relatively skilled labor scarce and interacts it with SKD and SUMGDP. Table 2 summarizes expected signs of the variables the M-M framework.

In addition to the variables just described, the M-M framework also includes additional control

${ }^{13}$ In our regressions, this variable will almost always take the value of "1" when we examine U.S. outbound data, because this suggests the U.S. is relatively skilled-labor abundant relative to the host country. Likewise, it will often take the value of " 0 " when our dependent variable is inbound FDI activity because the U.S. is the host country in such a circumstance. 
variables. First, distance (DISTANCE) is included to proxy for transport and other trade costs that will affect a firm's decision about whether to become an MNE. Second, trade openness for both the parent and host countries (T_OPEN ${ }_{\mathrm{i}}$ and $\mathrm{T}_{-} \mathrm{OPEN}_{\mathrm{j}}$ ) affect the MNE's ability to trade intermediates and final goods, which then affects the location of MNEs. Greater openness in the host country should lower FDI activity because it lowers trade frictions and makes exporting more attractive. Greater openness in the parent country should increase FDI, since it makes it easier to ship goods back to the parent country from foreign affiliates. FDI openness of the host country (F_OPEN) proxies for the costs of setting up an MNE, with greater openness expected to increase FDI activity. Finally, all regressions include a trend term. $^{14}$

We use this empirical M-M framework as our main specification to examine effects of bilateral tax treaties. However, we note that we get qualitatively similar results for the impact of tax treaties when using a gravity-type regression. Although these results have been omitted for space, they are available upon request.

As discussed earlier, tax treaties may alter investment incentives in a variety of ways. Unfortunately, most of these are difficult to quantify, and it is unclear how important the few quantifiable aspects are for the overall tax treaty effect. Thus, we begin with inclusion of a simple binary variable in the M-M empirical framework that takes the value of "1" when a U.S. treaty is in place for a given partner country and year to examine bilateral tax treaty effects. From this initial examination, however, we employ a variety of alternative specifications of this bilateral tax treaty variable that explores the hetereogeneity of tax treaty effects across countries and over time.

One additional concern is endogeneity of our dependent variable and the tax treaty variable. The U.S. may be negotiating treaties with only the countries for which there are large and/or increasing

${ }^{14} \mathrm{We}$ also tried including a squared trend term which does not affect qualitatively affect our coefficients of interest. Below we also discuss results from other extensions to our specification which further capture time dimensions of our data, including country-specific time trends and first differences. 
amounts of FDI activity. Such an endogeneity problem would bias our coefficient on tax treaties upwards and possibly cause a spurious positive correlation. In our sample, there are two types of US treaty partners: those with which the U.S. has had a bilateral tax treaty well before our sample begins, which we call old treaty partners, and those with which treaties are negotiated during our sample that spans mainly the 1970 s and 1980s, which we call the new treaty partners. Endogeneity problems are likely largest with the old treaty partners: Canada, Japan, Australia, New Zealand and the western European countries. However, since these treaties were in place well before our sample begins, we are already skeptical about our ability to separately identify tax treaty effects on FDI activity from other uncontrolled factors. Thus, our focus will be on the effects for new treaty countries, and for these partners there is little evidence of an endogeneity problem, as we next show.

Table 3 lists the new treaty countries, where they rank in terms of total FDI activity with the U.S. relative to other countries at the time of the treaty, as well as how many countries that were ranked ahead of the country did not yet have a bilateral tax treaty with the U.S. ${ }^{15}$ Table 3 clearly shows that the U.S. was not pursuing a strategy of signing bilateral tax treaties with countries that had the largest FDI activity with the U.S. during this period (1970-1990). As our estimates show below, these were also not countries that were suddenly experiencing new growth in FDI activity with the U.S. To the extent that one may believe endogeneity exists to bias our coefficient toward showing a positive relationship between new tax treaties and FDI, the negative effects we report below are even more surprising.

On a final note, we run empirical specifications on separate samples of U.S. outbound and U.S. inbound FDI activity. This allows us to examine whether bilateral tax treaties asymmetrically impact outbound FDI of U.S. firms versus FDI into the U.S. by foreign firms.

\section{B. Data}

${ }^{15}$ Table 3 also reports that for a number of countries, primarily former Soviet Bloc countries, data on FDI activity with the U.S. is unavailable. Thus, these countries are not part of our estimation. 
Empirical FDI studies have always been hampered by data difficulties. Missing or incomplete data for one or more variables often leads researchers to examine cross-sectional data, with little or no time series dimension. ${ }^{16}$ Data issues are also why researchers generally focus on U.S. data, as it is more complete and detailed than virtually any other countries' FDI statistics. Our approach is to collect data on inbound and outbound U.S. FDI activity for as many years as possible across as many countries as available. As a result, we have an unbalanced panel of 65 countries spanning up to 27 years - from 1966 through 1992 - depending on the particular dependent variable we employ. The ending date of 1992 was due to two data constraints. First, 1992 is the final reported year of the Penn-World Tables, which was an important source for a number of our study's independent variables. Second, the World Bank data we use to measure skill difference across countries ends around this time as well. Our ability to go back in time with our sample was typically constrained by reported years of U.S. FDI activity, our dependent variable, as we describe more below.

Following previous studies, we initially use affiliate sales in the host country as our indicator of FDI activity. However, statistics on affiliate sales activity are not available for nearly as many years as another indicator of FDI activity: FDI stock. Outbound FDI stock data go back as far as 1966 in some cases, whereas affiliate sales data are only available back to 1983 for outbound affiliate sales and 1984 for inbound affiliate sales. As one would guess, there are strong, statistically-significant correlations between affiliate sales and FDI stock: In our sample, the pairwise correlation is 0.88 for inbound FDI activity and 0.92 for outbound FDI. Thus, we also use FDI stock as an alternative dependent variable, as this allows us to substantially increase our sample observations. ${ }^{17}$ Both FDI activity variables are collected from

${ }^{16}$ Grubert and Mutti (1991) examine a cross-section of 33 countries for 1982, while Brainard (1997) samples U.S.-country-industry combinations across 63 tradeable industries and 27 countries for 1989. Markusen and Maskus (1999a, 1999b) examine an unbalanced panel data set of 36 U.S.-country pairs from 1986-1994. In contrast, this study examines an unbalanced panel of over 60 countries for up to 27 years.

${ }^{17}$ We discuss results from two other alternative measures of FDI activity, FDI flows and the number of affiliates, below. 
official BEA data available at the BEA's Internet site. We converted all FDI variables into thousands of real U.S. dollars using the U.S. GDP deflator as reported in the Economic Report of the President. A data appendix provides more details on these variables, as well as the other variables we employ in our study.

With respect to our independent variables, data on real GDP come from the Penn-World Tables. We also use these data to construct the M-M variables, SUMGDP, GDPDIFSQ, D2SKDGDPD, and D2SKDSUMG. The latter two variables also require data on skilled-labor differences between countries. For this we rely on a relatively new database constructed by World Bank researchers on total mean years of education across countries from 1950-1990. We use the difference in total mean years of education between the parent and host country as our measure of SKD (skilled-labor abundance difference), and D2 takes the value of "1" when the parent country has a higher total mean years of education. This differs from the data used by Markusen and Maskus (1999b) in construction of these variables related to skilled labor abundance. They use data from annual surveys conducted by the International Labour Organization to construct measures of skilled labor to total employment by country and year. These data were not available for many earlier years in our sample and, in addition, there were changes in how occupations were categorized into occupation types over time.

The main additional control variables we employ are distance (DISTANCE), trade openness (T_OPEN) and FDI openness (F_OPEN). Distance data come from the Bali Online Corporation (1999), while T_OPEN is taken from the Penn-World Tables and is defined as the ratio of the sum of imports and exports to GDP. Markusen and Maskus (1999b) use investment impediment indexes reported by the World Competitiveness Report of the World Economic Forum to measure F_OPEN. Since these data cover a relatively small set of years, we instead constructed an alternative F_OPEN measure defined as the host country's FDI stock net of any U.S.-owned FDI stock (to avoid endogeneity concerns) divided by its GDP. This is similar in construction to commonly-used trade openness measures. We only used this F_OPEN variable for our U.S. outbound FDI activity specifications, since such a measure for U.S. inbound FDI activity would not have any cross-sectional variation and just measure changes in U.S. FDI 
openness over time, which is highly correlated with the trend term that we include. Finally, information on U.S. bilateral tax treaties were collected from Diamond and Diamond (1998).

\section{Results}

\section{A. Initial Results}

Table 4 presents estimates for determinants of both inbound and outbound affiliate sales using the M-M specification with various tax treaty variables. We note that when we use U.S. inbound FDI data, subscript (i) refers to the foreign parent country and subscript (j) refers to the United States (the host country), while when we use U.S. outbound FDI data, subscript (i) refers to the United States (the parent country) and subscript (j) refers to the foreign host country. We begin with a specification that includes only a simple binary variable for whether the observation involves a treaty country or not, with column (1) displaying these results for inbound affiliate sales and column (4) displaying these results for outbound affiliate sales. For both samples, the data fit the overall model reasonably well with $\mathrm{R}^{2} \mathrm{~s}$ around 0.65 and an F-test statistic that rejects the null of zero slopes at the one percent significance level. In fact, the primary variables of the M-M model (SUMGDP, GDPDIFSQ, D2SKDGDPD, D2SKDSUMG, and D1SKDSUMG) are generally statistically significant and have predicted signs for a world that is dominated by horizontal MNEs. In other words, despite differences in sample and construction of some variables, our results are consistent with Carr, Markusen, and Maskus (2001) and Markusen and Maskus (1999a, 1999b) and suggest that horizontal MNEs are more prevalent than vertical MNEs.

Our variable of interest, capturing bilateral tax treaty effects, displays quite different results for inbound and outbound activity. On average, there appears to be little effect of bilateral tax treaties on inbound U.S. affiliate sales, but a statistically and economically significant effect on U.S. outbound affiliate activity. The estimate on outbound FDI activity suggests treaty partners have an additional $\$ 8.2$ billion in affiliate sales annually per country, which compares to an overall annual average of $\$ 15.8$ 
billion. This effect seems unusually high. A major concern is that this effect is being dominated by the old treaty partner countries, which are essentially the western European countries, Canada, Japan, Australia, and New Zealand. Despite the M-M control variables, the treaty variable may just be picking up unobserved characteristics of the old treaty partners that mean the U.S. has substantially more FDI activity with these countries regardless of any treaties in place.

We address these concerns in a number of ways. First, we explore heterogeneous treaty effects across new and old treaty partners. Columns (2) and (5) in Table 4 examine results for inbound and outbound affiliate sales, respectively, when we replace the treaty dummy variable with a new treaty dummy and an old treaty dummy. The results are startling. The coefficients on the new treaty country dummy variable are now negative and statistically significant. On the other hand, the effects for the old treaty partners are similar to the overall effects estimated in columns (1) and (4), except that the magnitude of the treaty variable for the U.S. outbound affiliate activity is now over twice as large. ${ }^{18}$ This still leaves the concern that unobserved differences not accounted for by the M-M framework are driving the coefficient estimates on the two treaty variables.

The obvious way to control for possible unobserved factors is to include time-invariant unobserved country-partner-specific fixed effects and columns (3) and (6) of Table 4 present estimates when we include these fixed effects into our specification. As one might guess, the fixed effects turn out to be quite important with $\mathrm{R}^{2} \mathrm{~s}$ now close to one and F-tests strongly supporting the inclusion of the fixed effects. However, the tradeoff is that, since bilateral tax treaties with old treaty partners occurred before our sample begins, inclusion of these fixed effects precludes the estimation of an old treaty dummy

${ }^{18}$ An earlier draft of this paper (Blonigen and Davies, 2000) also found no significant effect for the simple treaty dummy variable. In that version, we then moved towards a "treaty age" variable to measure vintage effects. There, we found that older treaties were significantly and positively correlated with FDI activity. Initially, we attributed this to significant lag effects from the treaties. Given the results below, however, the evidence suggests that this effect is driven by the particular experience of the old treaty countries. Unfortunately, given the limitations of the data set, we cannot say more on the effects of older treaties. 
variable. Because these fixed effects are so important for fitting the data, we necessarily focus on estimating treaty effects for only the new treaty partners in the rest of the paper, and concede that data constraints do not allow us to credibly estimate treaty effects for old treaty partners. ${ }^{19}$

Once we control for country-partner-specific fixed effects, we find that the coefficients on the new treaty dummy variable in columns (3) and (6) of Table 4 are still negative and statistically significant for both U.S. inbound and outbound affiliate sales, though the magnitude falls by $40-50$ percent. The estimated negative effects of treaties on FDI activity support to the notion that treaties are intended to reduce tax evasion rather than promote new FDI. Since some activity on the margin may be driven by the ability to engage in transfer pricing or other types of evasion, a treaty which eliminates this ability could lead to this result.

In fact, despite the drop in magnitude of the coefficients from the column (2) and (5) estimates, the column (3) and (6) estimates indicate very large effects on FDI activity. Column (3) estimates suggest that a new treaty leads to annual loss of $\$ 9.7$ billion in inbound affiliate sales which is unreasonably large compared to an average of $\$ 284$ million in annual inbound affiliate sales by new treaty countries during our sample. The estimated annual loss for a new treaty on outbound sales is $\$ 2.5$ billion, which is a potentially more reasonable figure compared to an average of $\$ 4.0$ billion in annual outbound affiliate sales by new treaty countries during our sample. In section IV.B. below we explore alternative reasons for such large coefficient estimates and present modified M-M specifications that lead to more reasonable results. Before proceeding, however, we first verify that use of FDI stock data for our dependent variable yields qualitatively identical results using these initial specifications.

As mentioned earlier, U.S. BEA data on affiliate sales only go back to the early 1980s, while FDI

${ }^{19}$ Credible estimation of the old treaty effects would first require consistent data on FDI activity back to World War II at least. In addition, one would have to control for the endogeneity issues, since these old-treaty countries were clearly the U.S.'s main economic partners. Finally, one would have to control for the many economic factors, such as reconstruction after WWII, that were occurring at the time. 
stock data go as far back as to 1966 in some cases. Not only does the use of affiliate sales data limit the number of observations, but another importance consequence of the much shorter time period is that, as with the old partner treaty countries, the effects for new treaty partner countries that negotiated treaties in the 1970s and early 1980s are completely captured in the country-partner-specific fixed effects -- not in the new partner treaty variable. ${ }^{20}$ Using FDI stock as our dependent variable means a substantial increase in observations and the time dimension of our data, particularly for outbound FDI activity. Table 5 repeats results of Table 4 empirical specifications when using real FDI stock as the dependent variable, rather than affiliate sales. As with the affiliate sales data, the M-M framework fits both U.S. inbound and outbound FDI stock data decently well, and again the coefficient estimates support the predictions of the horizontal MNE theoretical model. The treaty variables reveal a similar pattern to the affiliate sales results as well. The effects of bilateral tax treaties with the U.S. appear to have negative effects on U.S. FDI activity with new treaty partner countries, even after controlling for country-partner-specific fixed effects. However, once again the estimated new treaty effects seem unreasonably large. Inbound FDI stock with new treaty partners is estimated to be $\$ 9.3$ billion lower annually, even though the average inbound stock for these countries is just $\$ 89$ million. Outbound FDI stock is estimated to be $\$ 880$ million lower as compared to an average of $\$ 911$ million of outbound FDI stock in new treaty partner countries.

\section{B. Alternative Specifications}

The unreasonably large estimated new treaty effects leads to an exploration of modified M-M empirical frameworks in this section. The first modification we explore is allowing interactions between the M-M control variables and a dummy variable that indicates whether the partner country is "rich" or "poor". We define the "rich" countries as Japan, Canada, Australia, New Zealand, and the western European countries, which are also the old treaty partners of the U.S. By constraining the coefficient on

\footnotetext{
${ }^{20}$ In fact, China, Tunisia, Cyprus, Indonesia, India, and Spain are the only countries with new treaties that begin after our affiliate sales data begin and before our sample ends.
} 
the M-M control variables to be identical across country pairs, we assume that changes in these variables have the same effect for both rich and poor countries, which may not be correct. If growth in M-M variables, such as SUMGDP, translate into much larger increases in FDI activity for rich countries than poor countries, the model will be overestimating how much growth in SUMGDP should increase FDI activity for poor countries. Thus, when one includes a new treaty variable for a poor country towards the latter half of the time series, the coefficient may be biased negative to compensate.

This discussion also brings up the issue of time series problems in the data, which have not been addressed in any previous papers using the M-M model. Given an unbalanced panel of countries with varying and short time series, there are no easy or standard ways of handling this issue. A regression of the dependent variables on its one-period lag results in very high and statistically significant coefficients, even after controlling for other variables. The control regressors are likely not stationary for many crosssectional units as well, despite being defined in real terms. Thus, we modify our estimation in two ways. In the first alternative, we continue to specify the regression in levels with fixed effects, but replace the general time trend with country-partner specific time trends. The second alternative is to estimate the regression in first differences.

Table 6 shows our results for inbound and outbound affiliate sales as we modify the M-M framework to account for these issues. Columns (1) and (4) of Table 6 show a specification when we add country-specific time trends to our fixed effects model. The M-M control variables perform similar to before, but the impact on the new treaty variable is dramatic. For inbound affiliate sales, the coefficient falls from $-\$ 9.7$ billion to $-\$ 525$ million and is now statistically insignificant. The new treaty coefficient on outbound affiliate sales falls from $-\$ 2.5$ billion to $-\$ 1.1$ billion once country-specific trend terms are included.

In columns (2) and (5), we continue to have country-specific trends, but also allow the coefficients on SUMGDP, GDPDIFSQ, F_OPEN, T_OPEN $\mathrm{i}_{\mathrm{i}}$ and $\mathrm{T}_{-} \mathrm{OPEN}_{\mathrm{j}}$ to differ across rich and poor 
countries by interacting these variables with a "RICH COUNTRY" dummy variable. ${ }^{21}$ The results strongly confirm that imposing identical coefficients on these $\mathrm{M}-\mathrm{M}$ control variables across rich and poor countries is incorrect. The M-M controls, which without the interaction terms, are capturing only the effects for poor countries, are now much smaller and imprecisely estimated. However, combining these effects with the interaction terms, we find large and precise estimates for the rich countries. Thus, the differences in explanatory power of the M-M variables for FDI activity across rich and poor countries is highly significant, both statistically and in terms of magnitude. In terms of inbound affiliate sales, including the interaction terms substantially reduces the absolute size of the new treaty coefficient, which is consistent with the explanation given above. However, the new treaty coefficient for outbound sales remains about the same, suggesting that heterogeneity across parent countries is a larger issue than across host countries.

In columns (3) and (6), we present results from estimating the model in first differences, while continuing to include the M-M rich-poor country interactions. The treaty variable is now a dummy variable that takes the value of " 1 " in the treaty year, and is, thus, capturing any one-time adjustments that occur to FDI activity growth in the treaty year. The fit of these first-differences specifications is quite good with an $\mathrm{R}^{2}$ of 0.56 for the inbound affiliate sales data and one of 0.25 for the outbound affiliate sales. F-tests clearly reject the null of jointly zero slopes at the one percent level as well. The M-M variables generally perform as before in terms of signs and statistical significance. In terms of the new treaty coefficients, the effect of new treaties on inbound affiliate sales is estimated with a small negative coefficient that is insignificant. Similarly, the effect of new treaties on outbound affiliate sales is smaller than before as well.

Table 7 replicates Table 6 using FDI stock data rather than affiliate sales data, but despite the

${ }^{21}$ We do not interact D2SKDGDPD, D2SKDSUMG or D1SKDSUMG because the way they are defined (particularly, whether they are more skilled labor abundant or not relative to the U.S.) precludes any variation for the poor countries. 
large differences in sample size and countries that are included in the new treaty effects, we get qualitatively identical answers. In particular, including rich-poor interaction terms and controlling for time series concerns through either country-specific trends or first differences substantially reduces the coefficients into ranges that seem reasonable given the average levels. As with the affiliate sales regressions, the first differences specification estimates negative effects of new treaties on FDI stock, however, the effect on outbound FDI stock is statistically significant as well. The estimates suggest that new treaties lead to a drop of $\$ 188$ million in outbound FDI stock, which is significant (but not unreasonably large) relative to an average of $\$ 911$ million of outbound FDI stock in new treaty partner countries.

\section{Exploring Year-by-Year New Treaty Effects}

By specifying only a simple binary variable to capture the new-partner treaty effects for the levels regressions, we assume that the new treaty effects are identical for all years after a treaty is in place. By specifying a dummy variable for only the treaty year when we first difference the data, we assume the effects on FDI growth all take place in the treaty year. With either specification we may be missing important information on timing issues connected with these treaty effects. For example, do these negative treaty effects occur only in the year of the treaty or is there a dampening effect on activity for all years after a treaty is in place? Another issue is the possibility of anticipatory effects in the period before the treaty is actually ratified and comes into place.

Table 8 explores these issues by reporting estimates from a first differences specification where we replace the new treaty binary variable with individual year effects for each year surrounding a treaty (from 3 year prior to 5 years after). This specification is similar in all other ways to that estimated in columns (3) and (6) of Tables 6 and 7, therefore we only report the coefficients from the individual year effects for the sake of space. We note that this assumes that these individual year effects are identical across the new treaty partner countries, but we discuss relaxing this assumption below. The model is estimated for both inbound and outbound activity for both affiliate sales and FDI stock data.

For the FDI stock data (columns (3) and (4) of Table 8) the effects are concentrated around the 
treaty year. There is a large and statistically significant negative effect in the treaty year for outbound FDI stock (\$192 million drop) and a similar drop for inbound FDI stock (\$266 million drop) in the year after. All other year effects in these FDI stock regressions are statistically insignificant. The affiliate sales regressions suggest a different picture. The outbound affiliate sales results (column (2)) suggest a number of statistically significant drops in the growth rate in the second through the fourth years after a treaty is signed. This may not be inconsistent with the FDI stock regressions if changes in affiliate sales follow some lagged relationship with changes in FDI stock. The inbound affiliate sales regressions show statistically insignificant effects, except for statistically significant positive effects in the fourth and fifth years after a treaty.

The overall message from the estimates reported in Table 8 is that for the inbound FDI activity (whether using affiliate sales or FDI stock data), there are no statistically significant effects from the treaties though there are generally negative coefficient for the individual year effects. For the outbound FDI activity, there is a statistically significant negative effect of the treaty in the particular year of the treaty (and also for the year immediately after the treaty for affiliate sales), but no significant effects for other years surrounding the treaty. Thus, the important new piece of information we gain from Table 8 is that these new-partner treaties seem to lead to one-time adjustments at the time of the treaty, but no worsening of FDI activity after that. This too is consistent with the story that treaties drive out firms who engage in FDI in large part to exploit tax evasion possibilities.

\section{Individual New Partner Country Effects}

All our regressions to this point have assumed identical treaty effects across new treaty partner countries, which may mask important heterogeneity across these new partner countries. Table 9 explores this by estimating the first differences model for outbound FDI stock with individual treaty-year dummies for each separate partner country. Except for Morocco, we estimate negative treaty effects for all countries. These negative effects are statistically significant for China, Egypt, Indonesia, Korea, 
Phillippines, and Spain. Thus, there is heterogeneity in treaty effects across countries, but negative coefficients are prevalent. Columns (2) and (3) give two metric by which to judge the magnitude of these effects: FDI stock in the treaty year and average FDI stock during the sample. The estimated treaty effects seem reasonable in magnitude across the countries, with the exception of Cyprus, which is has a coefficient that is imprecisely estimated.

\section{E. Alternative Dependent Variables}

In addition to data on affiliate sales and FDI stock, there also exists BEA data on FDI flows and numbers of affiliates, which may be reasonably modeled by the empirical specification we use here. ${ }^{22}$ FDI flows are generally reported for the same number of years as the FDI stock and are obviously highly correlated as changes in FDI stock are exactly these FDI flows. In fact, our specifications above employing FDI stock and controlling for country-specific fixed effects and trends (or alternatively, in first differences) was essentially yielding estimates from net changes in FDI stock. Thus, it is not surprising that using the same M-M empirical framework to model these FDI flows we find qualitatively similar results with respect to new treaty partner effects.

Examining the effect of new treaties on number of affiliates is interesting, because to this point we cannot discern if the negative effect of new treaties on FDI activity stems from purely reductions (smaller increases) in FDI activity by existing firms, or if it also includes exits (less entry). Using number of affiliates as our dependent variable in the same M-M framework (both in levels and first differences), we estimate negative coefficients for both outbound and inbound, though in neither case are they statistically significant. We do not report the results on FDI flows or the number of affiliates here for

22 The BEA also reports net income which may be of particular interest. However, it is not clear that the M-M framework is appropriate for modeling FDI income flows, rather than FDI activity. In addition, since the reported variable is net income, there are endogeneity issues with our tax treaty variable, that may be difficult to control. 
brevity, but they are available upon request.

\section{Conclusion}

This paper estimates the effects of bilateral treaties governing the taxation of FDI for the first time. Though we our sample covers the most comprehensive set of countries and years to date, the data constraints allow us to only credibly estimate the effects of U.S. bilateral tax treaties that were implemented in the 1970s and 1980s, which we call "new" treaties. Generally, we find insignificant, or even negative, effects of these treaties on FDI activity, particularly with respect to outbound FDI activity. This is consistent with the hypothesis that tax treaties are intended to reduce tax evasion rather than promote new investment. This idea suggests that one might expect a decrease in FDI activity because the treaty drives out firms who were undertaking investment primarily for tax reasons. Given the finding that the drop in FDI growth occurs right around the time a new treaty is put into place, this hypothesis seems especially apt. Finally, it is important to note that this period of U.S. bilateral treaty activity is likely quite different from the treaties it signed with more established countries in the decade after WWII, so it is not clear that our results generalize to that period.

In closing, we wish to highlight that our estimation results in the paper go through a deliberate sequence of empirical specifications for two reasons. First, since this is the first time these effects have been estimated, we felt it was important to begin with the most basic specifications and then build off of them. Second, many "dirty" data issues suggested useful modifications of the baseline approach. In the process of exploring these alternative specifications, we found that assuming a common coefficient on MM model's control variables for rich and poor partner countries is incorrect. This result occurs despite the model's skilled-labor interaction terms that are intended to capture rich and poor partner country differences. This suggests a need for further work to develop an empirical model that more adequately fits heterogeneous country pairs. We also found that time series properties cannot be ignored when using 
panel data of FDI activity across countries. Thus, there remains a great deal to be explored in the area of tax treaties and FDI, and it is our hope that this paper provides a stimulus for future research. 
Table 1: List of U.S. Tax Treaties.

\begin{tabular}{|l|l|l|}
\hline Aruba (1986-1996) & India (1990-) & Phillippines (1977-) \\
\hline Australia (1953-) & Indonesia (1989-) & Poland (1976-) \\
\hline Austria (1956-) & Ireland (1952-) & Portugal (1994-) \\
\hline Barbados (1984-) & Israel (1993-) & Romania (1976-) \\
\hline Belgium (1948-) & Italy (1955-) & Russia (1993-) \\
\hline Canada (1941-) & Jamaica (1981-) & Trinidad and Tobago (1971-) \\
\hline China (1985-) & Japan (1954-) & Slovak Republic (1994-) \\
\hline Cyprus (1988-) & Kazakhstan (1993-) & South Africa (1953-1987, 1997-) \\
\hline Czech Republic (1995-) & Korea, Republic of (1977-) & Spain (1991-) \\
\hline Denmark (1948-) & Luxembourg (1963-) & Sweden (1940-) \\
\hline Egypt (1981-) & Malta (1981-1997) & Switzerland (1951-) \\
\hline Finland (1952-) & Mexico (1993-) & Tunisia (1986-) \\
\hline France (1940-) & Morocco (1978-) & Turkey (1997-) \\
\hline Germany (1954-)* & Netherlands (1949-) & Ukraine (1994-) \\
\hline Greece (1965-) & Netherlands Antilles (1948-1987) & United Kingdom (1945-) \\
\hline Honduras (1956-1966) & New Zealand (1948-) & U.S.S.R. (1977-1992)** \\
\hline Hungary (1980-) & Norway (1951-) & \\
\hline Iceland (1976-) & Pakistan (1958-) & \\
\hline
\end{tabular}

NOTES: * Extended to cover reunified Germany 1990. ** Treaty provisions extended to former members until individual treaties can be negotiated. 
Table 2: Expected Signs of Independent Variables in Markusen-Maskus Empirical Framework.

\begin{tabular}{lll}
\hline Independent Variables & Expected Signs \\
\hline \multirow{2}{*}{ SUMGDP } & & \\
& + & if Horizontal or Knowledge-Capital MNE models \\
GDPDIFSQ & 0 & if Vertical MNE model \\
& - & if Horizontal or Knowledge-Capital MNE models \\
D2SKDGDPD & 0 & if Vertical MNE model \\
& - & if Knowledge-Capital MNE model \\
D2SKDSUMG & 0 & if Horizontal or Vertical MNE models \\
& + & if Vertical or Knowledge-Capital MNE models \\
D1SKDSUMG & - & if Horizontal MNE model \\
& 0 & if Vertical or Knowledge-Capital MNE models \\
DISTANCE & - & if Horizontal MNE model \\
T_OPENi & $?$ & \\
& - & if Vertical or Knowledge-Capital MNE models \\
T_OPENj & 0 & if Horizontal MNE model \\
F_OPENj & + & \\
\hline
\end{tabular}


Table 3: Relative Rank of New U.S. Bilateral Tax Treaty Countries in U.S. Outward FDI Position in the Year the Treaty is Enacted, 1972-1992.

\begin{tabular}{|l|l|c|c|}
\hline Year & Country & $\begin{array}{l}\text { Rank of Country in Terms of } \\
\text { U.S. Outward FDI Stock (Out of } \\
\text { Approximately 70 Countries) }\end{array}$ & $\begin{array}{c}\text { Number of Countries Ahead } \\
\text { in Rankings With No Treaty }\end{array}$ \\
\hline \hline 1976 & $\begin{array}{l}\text { Iceland } \\
\text { Romania } \\
\text { Poland }\end{array}$ & $\begin{array}{c}57^{\text {th }} \\
\text { No FDI data available } \\
\text { No FDI data available }\end{array}$ & 38 \\
\hline 1977 & Philippines & $22^{\text {nd }}$ & NA \\
& Korea & $29^{\text {th }}$ & 8 \\
\hline 1978 & U.S.S.R. & No FDI data available & 10 \\
\hline 1980 & Morocco & $48^{\text {th }}$ & NA \\
\hline 1981 & Hungary & Egypt & 29 \\
& Jamaica & $26^{\text {th }}$ & NA \\
\hline 1985 & Malta & $32^{\text {nd }}$ & 10 \\
\hline 1986 & China & No FDI data available & NA \\
\hline 1988 & Tunisia & $35^{\text {th }}$ & 15 \\
\hline 1989 & Aruba & $51^{\text {st }}$ & 28 \\
\hline 1990 & Cyprus & No FDI data available & NA \\
\hline 1991 & Indonesia & $56^{\text {th }}$ & 32 \\
\hline Spain & $18^{\text {th }}$ & 6 \\
\hline
\end{tabular}

NOTES: FDI data may not be available for a number of reasons, but it is often due to such small volume that it would reveal proprietary information on individual investing firms. NA denotes "Not Applicable." 
Table 4: Estimates of treaty effects on U.S. INBOUND and OUTBOUND AFFILIATE SALES.

\begin{tabular}{|c|c|c|c|c|c|c|}
\hline \multirow[b]{3}{*}{ Regressors } & \multicolumn{6}{|c|}{ Dependent Variables and Empirical Models } \\
\hline & \multicolumn{3}{|c|}{ Affiliate Sales Inbound } & \multicolumn{3}{|c|}{ Affiliate Sales Outbound } \\
\hline & Pooled & Pooled & Fixed effects & Pooled & Pooled & Fixed effects \\
\hline \multicolumn{7}{|l|}{$\underline{\text { Treaty Variables: }}$} \\
\hline TREATY & $\begin{array}{c}-4138.1 \\
(3771.7)\end{array}$ & & & $\begin{array}{l}8187.6^{* *} \\
(1445.2)\end{array}$ & & \\
\hline NEW TREATY & & $\begin{array}{c}-16534.3^{* *} \\
(5766.9)\end{array}$ & $\begin{array}{l}-9703.4 * * \\
(3087.7)\end{array}$ & & $\begin{array}{l}-5343.5^{* *} \\
(1224.1)\end{array}$ & $\begin{array}{c}-2509.68^{*} \\
(1023.0)\end{array}$ \\
\hline OLD TREATY & & $\begin{array}{c}4991.6 \\
(3557.5)\end{array}$ & & & $\begin{array}{l}19061.6^{* *} \\
(2118.5)\end{array}$ & \\
\hline \multicolumn{7}{|l|}{ M-M Controls: } \\
\hline SUMGDPij & $\begin{array}{c}45.018 * * \\
(10.740)\end{array}$ & $\begin{array}{l}45.431 * * \\
(10.469)\end{array}$ & $\begin{array}{c}78.988^{* *} \\
(11.990)\end{array}$ & $\begin{array}{l}44.380 * * \\
(7.251)\end{array}$ & $\begin{array}{l}41.191 * * \\
(6.815)\end{array}$ & $\begin{array}{l}69.187 * * \\
(10.288)\end{array}$ \\
\hline GDPDIFSQij & $\begin{array}{c}-3.565 * * \\
(1.310)\end{array}$ & $\begin{array}{l}-3.419 * * \\
(1.284)\end{array}$ & $\begin{array}{l}-7.416^{* *} \\
(1.386)\end{array}$ & $\begin{array}{l}-8.790 * * \\
(1.016)\end{array}$ & $\begin{array}{c}-8.240 * * \\
(0.954)\end{array}$ & $\begin{array}{c}-9.720 * * \\
(1.514)\end{array}$ \\
\hline D2SKDGDPDij & $\begin{array}{c}-1043.5^{*} \\
(512.67)\end{array}$ & $\begin{array}{c}-990.84 * \\
(497.85)\end{array}$ & $\begin{array}{l}-748.10^{* *} \\
(232.24)\end{array}$ & $\begin{array}{c}-6.730 * * \\
(0.959)\end{array}$ & $\begin{array}{c}-6.148 \\
(0.864)\end{array}$ & $\begin{array}{r}-11.470 \\
\quad(2.204)\end{array}$ \\
\hline D2SKDSUMGij & $\begin{array}{r}-1037.9 * \\
(505.68)\end{array}$ & $\begin{array}{c}-985.46^{*} \\
(491.04)\end{array}$ & $\begin{array}{l}-734.06^{* *} \\
(229.19)\end{array}$ & $\begin{array}{c}-6.956^{* *} \\
(0.929)\end{array}$ & $\begin{array}{c}-6.122 \\
(0.838)\end{array}$ & $\begin{array}{r}-11.875 \\
(0.571)\end{array}$ \\
\hline D1SKDSUMGij & $\begin{array}{l}-2.069^{* *} \\
(0.269)\end{array}$ & $\begin{array}{l}-1.671^{* *} \\
(0.237)\end{array}$ & $\begin{array}{l}-4.989 * * \\
(0.797)\end{array}$ & $\begin{array}{l}-3.121 * * \\
(0.596)\end{array}$ & $\begin{array}{l}-3.703 * * \\
(0.644)\end{array}$ & $\begin{array}{l}-1.198^{* *} \\
(0.571)\end{array}$ \\
\hline DISTij & $\begin{array}{l}-1.245^{* *} \\
(0.435)\end{array}$ & $\begin{array}{l}-1.016^{* *} \\
(0.441)\end{array}$ & & $\begin{array}{l}-2.643^{* *} \\
(0.460)\end{array}$ & $\begin{array}{l}-2.465^{* *} \\
(0.419)\end{array}$ & \\
\hline F_OPEN & & & & $\begin{array}{c}20878 * * \\
(4679.5)\end{array}$ & $\begin{array}{l}23934.6^{* *} \\
(5422.2)\end{array}$ & $\begin{array}{c}2745.6 \\
(3054.1)\end{array}$ \\
\hline T_OPENi & $\begin{array}{c}-16.039 \\
(14.099)\end{array}$ & $\begin{array}{c}-14.045 \\
(14.074)\end{array}$ & $\begin{array}{c}-31.409 \\
(27.836)\end{array}$ & $\begin{array}{c}2478.8 \\
(1640.8)\end{array}$ & $\begin{array}{c}2196.3 \\
(1570.4)\end{array}$ & $\begin{array}{l}2431.5^{* *} \\
(383.48)\end{array}$ \\
\hline T_OPENj & $\begin{array}{c}60.739 \\
(2277.7)\end{array}$ & $\begin{array}{l}-130.10 \\
(2260.2)\end{array}$ & $\begin{array}{c}2001.7 \\
(794.71)\end{array}$ & $\begin{array}{c}23.901 \\
(14.113)\end{array}$ & $\begin{array}{c}19.304 \\
(15.384)\end{array}$ & $\begin{array}{c}-53.236^{* *} \\
(18.327)\end{array}$ \\
\hline R-squared & 0.63 & 0.65 & 0.98 & 0.68 & 0.71 & 0.99 \\
\hline F Test & $24.96 * *$ & $24.97 * *$ & $15.15^{* *}$ & $27.62 * *$ & $37.55^{* *}$ & $22.99 * *$ \\
\hline Sample Size & 396 & 396 & 396 & 556 & 556 & 556 \\
\hline
\end{tabular}

NOTES: Robust standard errors are in parentheses, with ** and * denoting statistical significance (twotailed test) at the 1 and 5 percent levels, respectively. 
Table 5: Estimates of treaty effects on U.S. INBOUND and OUTBOUND FDI STOCK.

\begin{tabular}{|c|c|c|c|c|c|c|}
\hline \multirow[b]{3}{*}{ Regressors } & \multicolumn{6}{|c|}{ Dependent Variables and Empirical Models } \\
\hline & \multicolumn{3}{|c|}{ FDI Stock Inbound } & \multicolumn{3}{|c|}{ FDI Stock Outbound } \\
\hline & Pooled & Pooled & Fixed effects & Pooled & Pooled & Fixed effects \\
\hline \multicolumn{7}{|l|}{ Treaty Variables: } \\
\hline TREATY & $\begin{array}{c}789.18 \\
(773.83)\end{array}$ & & & $\begin{array}{l}2936.8 * * \\
(430.94)\end{array}$ & & \\
\hline NEW TREATY & & $\begin{array}{l}-3737.6^{* *} \\
(1062.1)\end{array}$ & $\begin{array}{l}-9279.3 * * \\
(1927.8)\end{array}$ & & $\begin{array}{l}-1686.9^{* *} \\
(423.74)\end{array}$ & $\begin{array}{l}-879.94 * * \\
(192.41)\end{array}$ \\
\hline OLD TREATY & & $\begin{array}{c}3748.2 * * \\
(857.16)\end{array}$ & & & $\begin{array}{c}5180.4 * * \\
(535.78)\end{array}$ & \\
\hline \multicolumn{7}{|l|}{ M-M Controls: } \\
\hline SUMGDPij & $\begin{array}{l}7.460 * * \\
(2.190)\end{array}$ & $\begin{array}{l}6.773^{* *} \\
(2.144)\end{array}$ & $\begin{array}{l}29.015 * * \\
(3.981)\end{array}$ & $\begin{array}{c}10.032 * * \\
(1.596)\end{array}$ & $\begin{array}{l}9.157^{* *} \\
(1.535)\end{array}$ & $\begin{array}{l}10.140 * * \\
(1.208)\end{array}$ \\
\hline GDPDIFSQij & $\begin{array}{l}-1.128 * * \\
(0.337)\end{array}$ & $\begin{array}{l}-1.187 * * \\
(0.329)\end{array}$ & $\begin{array}{l}-3.192 * * \\
(0.522)\end{array}$ & $\begin{array}{l}-1.048^{* *} \\
(0.211)\end{array}$ & $\begin{array}{c}-0.960 * * \\
(0.204)\end{array}$ & $\begin{array}{c}-1.017 * * \\
(0.134)\end{array}$ \\
\hline D2SKDGDPDij & $\begin{array}{l}-283.31 \\
(332.63)\end{array}$ & $\begin{array}{l}-294.15 \\
(323.30)\end{array}$ & $\begin{array}{c}-95.162 \\
(85.443)\end{array}$ & $\begin{array}{l}-0.763^{* *} \\
(0.219)\end{array}$ & $\begin{array}{l}-0.661 * * \\
(0.201)\end{array}$ & $\begin{array}{c}-0.948 * * \\
(0.223)\end{array}$ \\
\hline D2SKDSUMGij & $\begin{array}{c}-281.14 \\
(328.16)\end{array}$ & $\begin{array}{c}-291.84 \\
(318.95)\end{array}$ & $\begin{array}{c}-92.699 \\
(84.299)\end{array}$ & $\begin{array}{l}-0.894 * * \\
(0.217)\end{array}$ & $\begin{array}{l}-0.725^{* *} \\
(0.199)\end{array}$ & $\begin{array}{c}-1.032 \\
(0.233)\end{array}$ \\
\hline D1SKDSUMGij & $\begin{array}{l}-0.384 * * \\
(0.058)\end{array}$ & $\begin{array}{c}-0.278^{* *} \\
(0.050)\end{array}$ & $\begin{array}{l}-1.186^{* *} \\
(0.177)\end{array}$ & $\begin{array}{l}-0.738^{* *} \\
(0.092)\end{array}$ & $\begin{array}{c}-0.798^{* *} \\
(0.095)\end{array}$ & $\begin{array}{l}-0.313^{* *} \\
(0.059)\end{array}$ \\
\hline DISTij & $\begin{array}{c}-0.428 * * \\
(0.096)\end{array}$ & $\begin{array}{c}-0.373 * * \\
(0.093)\end{array}$ & & $\begin{array}{l}-1.021^{* *} \\
(0.128)\end{array}$ & $\begin{array}{l}-1.008^{* *} \\
(0.124)\end{array}$ & \\
\hline F_OPEN & & & & $\begin{array}{l}6085.7 * * \\
(1643.0)\end{array}$ & $\begin{array}{c}6657.3^{* *} \\
(1735.2)\end{array}$ & $\begin{array}{c}-369.04 \\
(1173.9)\end{array}$ \\
\hline T_OPENi & $\begin{array}{c}3.827 \\
(4.212)\end{array}$ & $\begin{array}{c}4.240 \\
(4.183)\end{array}$ & $\begin{array}{c}-17.882 \\
(12.277)\end{array}$ & $\begin{array}{c}-16.720 \\
(126.37)\end{array}$ & $\begin{array}{c}-5.307 \\
(124.67)\end{array}$ & $\begin{array}{c}4.065 \\
(27.018)\end{array}$ \\
\hline T_OPENj & $\begin{array}{c}263.19 \\
(258.39)\end{array}$ & $\begin{array}{c}306.07 \\
(255.55)\end{array}$ & $\begin{array}{c}313.45^{*} \\
(138.19)\end{array}$ & $\begin{array}{c}-3.300 \\
(3.136)\end{array}$ & $\begin{array}{c}-3.508 \\
(3.278)\end{array}$ & $\begin{array}{c}-8.757 * * \\
(3.879)\end{array}$ \\
\hline R-squared & 0.37 & 0.39 & 0.90 & 0.36 & 0.38 & 0.96 \\
\hline F Test & $13.22 * *$ & $13.49 * *$ & $10.93 * *$ & $23.85^{* *}$ & $33.36^{* *}$ & $39.50 * *$ \\
\hline Sample Size & 731 & 731 & 731 & 1355 & 1355 & 1355 \\
\hline
\end{tabular}

NOTES: Robust standard errors are in parentheses, with ** and * denoting statistical significance (twotailed test) at the 1 and 5 percent levels, respectively. 
Table 6: Estimates of treaty effects on U.S. INBOUND and OUTBOUND AFFILIATE SALES.

\begin{tabular}{|c|c|c|c|c|c|c|}
\hline \multirow[b]{3}{*}{ Regressors } & \multicolumn{6}{|c|}{ Dependent Variables and Empirical Models } \\
\hline & \multicolumn{3}{|c|}{ Inbound Affiliate Sales } & \multicolumn{3}{|c|}{ Outbound Affiliate Sales } \\
\hline & $\begin{array}{l}\text { Fixed effects } \\
\text { and country- } \\
\text { specific trends }\end{array}$ & $\begin{array}{l}\text { Fixed effects } \\
\text { and country- } \\
\text { specific trends }\end{array}$ & $\begin{array}{c}\text { First } \\
\text { differences }\end{array}$ & $\begin{array}{l}\text { Fixed effects } \\
\text { and country- } \\
\text { specific trends }\end{array}$ & $\begin{array}{l}\text { Fixed effects } \\
\text { and country- } \\
\text { specific trends }\end{array}$ & $\begin{array}{c}\text { First } \\
\text { differences }\end{array}$ \\
\hline NEW TREATY & $\begin{array}{l}-525.98 \\
(1046.8)\end{array}$ & $\begin{array}{l}-91.486 \\
(138.46)\end{array}$ & $\begin{array}{c}-55.52 \\
(271.86)\end{array}$ & $\begin{array}{l}-1090.1 \\
(781.75)\end{array}$ & $\begin{array}{r}-1115.7 \\
(720.6)\end{array}$ & $\begin{array}{c}-383.54 \\
(417.80)\end{array}$ \\
\hline \multicolumn{7}{|l|}{ M-M Controls: } \\
\hline SUMGDPij & $\begin{array}{l}53.632 * * \\
(14.356)\end{array}$ & $\begin{array}{c}2.614 \\
(3.047)\end{array}$ & $\begin{array}{c}8.714^{*} \\
(3.775)\end{array}$ & $\begin{array}{c}37.284^{*} \\
(16.982)\end{array}$ & $\begin{array}{c}-20.169 \\
(13.913)\end{array}$ & $\begin{array}{l}-11.461 \\
(11.326)\end{array}$ \\
\hline GDPDIFSQij & $\begin{array}{l}-4.846^{* *} \\
(1.503)\end{array}$ & $\begin{array}{c}0.069 \\
(0.177)\end{array}$ & $\begin{array}{l}-0.202 \\
(0.147)\end{array}$ & $\begin{array}{l}-5.672^{* *} \\
(2.178)\end{array}$ & $\begin{array}{c}1.970 \\
(1.812)\end{array}$ & $\begin{array}{l}1.675 \\
(1.406)\end{array}$ \\
\hline D2SKDGDPDij & $\begin{array}{c}410.51 \\
(479.58)\end{array}$ & $\begin{array}{l}-106.17 \\
(491.10)\end{array}$ & $\begin{array}{l}-284.72 \\
(273.44)\end{array}$ & $\begin{array}{l}-1.718 \\
(2.386)\end{array}$ & $\begin{array}{l}-5.666^{*} \\
(2.560)\end{array}$ & $\begin{array}{c}3.373 \\
(2.050)\end{array}$ \\
\hline D2SKDSUMGij & $\begin{array}{c}403.85 \\
(471.73)\end{array}$ & $\begin{array}{l}-105.92 \\
(483.16)\end{array}$ & $\begin{array}{l}-281.32 \\
(269.51)\end{array}$ & $\begin{array}{l}-1.415 \\
(2.466)\end{array}$ & $\begin{array}{l}-6.312 * \\
(2.647)\end{array}$ & $\begin{array}{c}2.745 \\
(2.046)\end{array}$ \\
\hline D1SKDSUMGij & $\begin{array}{l}-3.171^{* *} \\
(0.812)\end{array}$ & $\begin{array}{c}-0.609 \\
(0.443)\end{array}$ & $\begin{array}{l}-0.779 \\
(0.465)\end{array}$ & $\begin{array}{c}-0.776 \\
(0.494)\end{array}$ & $\begin{array}{l}-3.659 * \\
(1.528)\end{array}$ & $\begin{array}{l}-1.192 \\
(1.466)\end{array}$ \\
\hline F_OPEN & & & & $\begin{array}{l}-4455.7 \\
(3964.1)\end{array}$ & $\begin{array}{r}-12165^{*} \\
(5175.1)\end{array}$ & $\begin{array}{l}-5440.4 \\
(3701.4)\end{array}$ \\
\hline T_OPENi & $\begin{array}{c}0.215 \\
(19.025)\end{array}$ & $\begin{array}{l}-2.326 \\
(5.068)\end{array}$ & $\begin{array}{l}-2.930 \\
(5.547)\end{array}$ & $\begin{array}{l}2083.2 * * \\
(360.14)\end{array}$ & $\begin{array}{c}201.11 \\
(225.21)\end{array}$ & $\begin{array}{l}406.62 * * \\
(138.57)\end{array}$ \\
\hline T_OPENj & $\begin{array}{l}1653.7 * * \\
(329.39)\end{array}$ & $\begin{array}{c}120.72 \\
(83.807)\end{array}$ & $\begin{array}{l}229.30^{*} \\
(104.21)\end{array}$ & $\begin{array}{l}-58.383^{*} \\
(24.452)\end{array}$ & $\begin{array}{l}-12.817 \\
(23.142)\end{array}$ & $\begin{array}{c}-8.775 \\
(10.483)\end{array}$ \\
\hline $\begin{array}{l}\text { SUMGDPij } \times \\
\text { RICH COUNTRY }\end{array}$ & & $\begin{array}{l}102.19 * * \\
(30.584)\end{array}$ & $\begin{array}{l}90.940 * * \\
(15.509)\end{array}$ & & $\begin{array}{l}81.567 * * \\
(28.969)\end{array}$ & $\begin{array}{l}52.066^{* *} \\
(16.042)\end{array}$ \\
\hline $\begin{array}{l}\text { GDPDIFSQij } \times \\
\text { RICH COUNTRY }\end{array}$ & & $\begin{aligned}- & 13.024 * * \\
& (3.981)\end{aligned}$ & $\begin{aligned}- & 11.309 * * \\
& (2.219)\end{aligned}$ & & $\begin{aligned}- & 12.001 * * \\
& (4.035)\end{aligned}$ & $\begin{array}{l}-8.100^{* *} \\
(2.179)\end{array}$ \\
\hline $\begin{array}{l}\text { F_OPEN } \times \text { RICH } \\
\text { COUNTRY }\end{array}$ & & & & & $\begin{array}{l}56045^{*} \\
(25279)\end{array}$ & $\begin{array}{c}23503 \\
(15522)\end{array}$ \\
\hline $\begin{array}{l}\text { T_OPENi } \times \text { RICH } \\
\text { COUNTRY }\end{array}$ & & $\begin{array}{c}86.980 \\
(67.805)\end{array}$ & $\begin{array}{r}120.74 * \\
(58.230)\end{array}$ & & $\begin{array}{l}3991.3 * * \\
(831.66)\end{array}$ & $\begin{array}{l}2513.5^{* *} \\
(681.47)\end{array}$ \\
\hline
\end{tabular}


T_OPENj $\times$ RICH COUNTRY

R-squared

0.997

$27.23 * *$

396
$2860.1 * *$

(604.9)

0.998

$39.81 * *$

396
$1660.1^{* *}$

(467.01)

0.559

$7.31 * *$

337
- 297.99*

(99.074)

- 193.97**

(65.984)

0.245

$4.18^{* *}$

464

NOTES: Robust standard errors are in parentheses, with ** and * denoting statistical significance (twotailed test) at the 1 and 5 percent levels, respectively. 
Table 7: Estimates of treaty effects on U.S. INBOUND and OUTBOUND FDI STOCK.

\begin{tabular}{|c|c|c|c|c|c|c|}
\hline \multirow[b]{3}{*}{ Regressors } & \multicolumn{6}{|c|}{ Dependent Variables and Empirical Models } \\
\hline & \multicolumn{3}{|c|}{ Inbound FDI Stock } & \multicolumn{3}{|c|}{ Outbound FDI Stock } \\
\hline & $\begin{array}{l}\text { Fixed effects } \\
\text { and country- } \\
\text { specific trends }\end{array}$ & $\begin{array}{l}\text { Fixed effects } \\
\text { and country- } \\
\text { specific trends }\end{array}$ & $\begin{array}{c}\text { First } \\
\text { differences }\end{array}$ & $\begin{array}{l}\text { Fixed effects } \\
\text { and country- } \\
\text { specific trends }\end{array}$ & $\begin{array}{l}\text { Fixed effects } \\
\text { and country- } \\
\text { specific trends }\end{array}$ & $\begin{array}{c}\text { First } \\
\text { differences }\end{array}$ \\
\hline NEW TREATY & $\begin{array}{l}-847.47 \\
(582.56)\end{array}$ & $\begin{array}{c}96.662 \\
(77.107)\end{array}$ & $\begin{array}{c}59.387 \\
(108.92)\end{array}$ & $\begin{array}{l}-225.23 \\
(181.06)\end{array}$ & $\begin{array}{l}-132.86 \\
(163.95)\end{array}$ & $\begin{array}{l}-188.04^{*} \\
(81.812)\end{array}$ \\
\hline \multicolumn{7}{|l|}{ M-M Controls: } \\
\hline SUMGDPij & $\begin{array}{l}30.202 * * \\
(9.125)\end{array}$ & $\begin{array}{c}0.052 \\
(0.892)\end{array}$ & $\begin{array}{c}0.410 \\
(1.011)\end{array}$ & $\begin{array}{c}3.596 * \\
(0.002)\end{array}$ & $\begin{array}{l}-2.568 * * \\
(0.635)\end{array}$ & $\begin{array}{c}-0.079 \\
(0.828)\end{array}$ \\
\hline GDPDIFSQij & $\begin{array}{l}-3.311^{* *} \\
(1.070)\end{array}$ & $\begin{array}{c}-0.034 \\
(0.043)\end{array}$ & $\begin{array}{c}-0.043 \\
(0.035)\end{array}$ & $\begin{array}{c}0.125 \\
(0.150)\end{array}$ & $\begin{array}{l}0.437 * * \\
(0.075)\end{array}$ & $\begin{array}{c}0.064 \\
(0.098)\end{array}$ \\
\hline D2SKDGDPDij & $\begin{array}{l}214.69^{* *} \\
(61.924)\end{array}$ & $\begin{array}{l}-27.465 \\
(99.770)\end{array}$ & $\begin{array}{c}55.248 \\
(68.531)\end{array}$ & $\begin{array}{l}1.411 * * \\
(0.239)\end{array}$ & $\begin{array}{l}1.423 * * \\
(0.203)\end{array}$ & $\begin{array}{l}0.492 * * \\
(0.156)\end{array}$ \\
\hline D2SKDSUMGij & $\begin{array}{l}211.41 * * \\
(60.958)\end{array}$ & $\begin{array}{l}-26.830 \\
(98.157)\end{array}$ & $\begin{array}{c}54.737 \\
(67.705)\end{array}$ & $\begin{array}{l}0.870 * * \\
(0.237)\end{array}$ & $\begin{array}{l}1.263 * * \\
(0.046)\end{array}$ & $\begin{array}{l}0.408 * * \\
(0.164)\end{array}$ \\
\hline D1SKDSUMGij & $\begin{array}{l}-1.066^{* *} \\
(0.276)\end{array}$ & $\begin{array}{c}0.014 \\
(0.135)\end{array}$ & $\begin{array}{l}-0.187 \\
(0.136)\end{array}$ & $\begin{array}{l}-0.281 \\
(0.153)\end{array}$ & $\begin{array}{c}-0.372 \\
(0.197)\end{array}$ & $\begin{array}{c}0.022 \\
(0.140)\end{array}$ \\
\hline F_OPEN & & & & $\begin{array}{l}-1358.4 \\
(799.11)\end{array}$ & $\begin{array}{l}-1974.6^{* *} \\
(551.77)\end{array}$ & $\begin{array}{l}-2987.6^{* *} \\
(804.84)\end{array}$ \\
\hline T_OPENi & $\begin{array}{c}8.067 \\
(6.313)\end{array}$ & $\begin{array}{c}1.960 * \\
(0.807)\end{array}$ & $\begin{array}{c}0.497 \\
(1.186)\end{array}$ & $\begin{array}{l}109.13 * * \\
(25.649)\end{array}$ & $\begin{array}{c}41.434 \\
(11.739)\end{array}$ & $\begin{array}{c}1.310 \\
(12.286)\end{array}$ \\
\hline T_OPENj & $\begin{array}{c}209.54 \\
(60.090)\end{array}$ & $\begin{array}{c}-1.510 \\
(10.623)\end{array}$ & $\begin{array}{c}59.387 \\
(36.073)\end{array}$ & $\begin{array}{r}-16.804 \\
(3.416)\end{array}$ & $\begin{array}{l}-4.304^{* *} \\
(1.440)\end{array}$ & $\begin{array}{l}-0.842 \\
(1.375)\end{array}$ \\
\hline $\begin{array}{l}\text { SUMGDPij } \times \\
\text { RICH COUNTRY }\end{array}$ & & $\begin{array}{l}67.475^{* *} \\
(18.325)\end{array}$ & $\begin{array}{l}41.786 * * \\
(6.461)\end{array}$ & & $\begin{array}{l}13.751 * * \\
(2.647)\end{array}$ & $\begin{array}{l}7.218^{* *} \\
(1.693)\end{array}$ \\
\hline $\begin{array}{l}\text { GDPDIFSQij } \times \\
\text { RICH COUNTRY }\end{array}$ & & $\begin{array}{l}-9.310^{* *} \\
(2.513)\end{array}$ & $\begin{array}{l}-5.461 * * \\
(0.924)\end{array}$ & & $\begin{array}{l}-1.464 * * \\
(0.324)\end{array}$ & $\begin{array}{l}-0.931 * * \\
(0.246)\end{array}$ \\
\hline $\begin{array}{l}\text { F_OPEN } \times \text { RICH } \\
\text { COUNTRY }\end{array}$ & & & & & $\begin{array}{l}13014.0^{* *} \\
(3913.9)\end{array}$ & $\begin{array}{l}-6572.8 \\
(3499.3)\end{array}$ \\
\hline $\begin{array}{l}\text { T_OPENi } \times \text { RICH } \\
\text { COUNTRY }\end{array}$ & & $\begin{array}{l}-3.385 \\
(25.456)\end{array}$ & $\begin{array}{l}-16.846 \\
(26.094)\end{array}$ & & $\begin{array}{l}344.37 * * \\
(68.174)\end{array}$ & $\begin{array}{l}306.07 * * \\
(54.565)\end{array}$ \\
\hline
\end{tabular}




\begin{tabular}{|c|c|c|c|c|c|c|}
\hline $\begin{array}{l}\text { T_OPENj } \times \text { RICH } \\
\text { COUNTRY }\end{array}$ & & $\begin{array}{c}474.03 \\
(144.29)\end{array}$ & $\begin{array}{c}82.202 \\
(196.12)\end{array}$ & & $\begin{array}{l}-104.21 * * \\
(20.882)\end{array}$ & $\begin{array}{l}-44.871 * * \\
(14.371)\end{array}$ \\
\hline R-squared & 0.981 & 0.985 & 0.335 & 0.986 & 0.987 & 0.168 \\
\hline F Test & $16.86^{* *}$ & $21.75 * *$ & $4.75^{* *}$ & $33.04 * *$ & $42.68 * *$ & $8.88^{* *}$ \\
\hline Sample Size & 731 & 731 & 640 & 1355 & 1355 & 1257 \\
\hline
\end{tabular}

NOTES: Robust standard errors are in parentheses, with ** and $*$ denoting statistical significance (twotailed test) at the 1 and 5 percent levels, respectively. 
Table 8: Estimates of treaty effects on U.S. INBOUND and OUTBOUND AFFILIATE SALES and FDI STOCK.

\begin{tabular}{|c|c|c|c|c|}
\hline \multirow[b]{3}{*}{ Regressors } & \multicolumn{4}{|c|}{ Dependent Variables and Empirical Models } \\
\hline & \multicolumn{2}{|c|}{ Affiliate Sales } & \multicolumn{2}{|c|}{ FDI Stock } \\
\hline & Inbound & Outbound & Inbound & Outbound \\
\hline TREATY_-3 & $\begin{array}{c}74.572 \\
(178.39)\end{array}$ & $\begin{array}{c}-626.84 \\
(872.68)\end{array}$ & $\begin{array}{l}-14.105 \\
(35.530)\end{array}$ & $\begin{array}{r}-107.31 \\
(159.57)\end{array}$ \\
\hline TREATY_-2 & $\begin{array}{c}-74.478 \\
(126.93)\end{array}$ & $\begin{array}{c}-350.95 \\
(802.37)\end{array}$ & $\begin{array}{c}-22.283 \\
(60.216)\end{array}$ & $\begin{array}{c}-5.460 \\
(149.97)\end{array}$ \\
\hline TREATY_-1 & $\begin{array}{c}77.564 \\
(135.49)\end{array}$ & $\begin{array}{c}374.11 \\
(930.14)\end{array}$ & $\begin{array}{c}21.494 \\
(47.912)\end{array}$ & $\begin{array}{c}-58.457 \\
(136.83)\end{array}$ \\
\hline TREATY YEAR & $\begin{array}{c}-13.252 \\
(277.94)\end{array}$ & $\begin{array}{c}-432.36 \\
(439.71)\end{array}$ & $\begin{array}{c}52.187 \\
(112.88)\end{array}$ & $\begin{array}{c}-192.71 * \\
(83.257)\end{array}$ \\
\hline TREATY_+1 & $\begin{array}{c}117.49 \\
(174.88)\end{array}$ & $\begin{array}{c}-280.54 \\
(407.19)\end{array}$ & $\begin{array}{c}-266.45^{*} \\
(114.55)\end{array}$ & $\begin{array}{c}-3.090 \\
(42.731)\end{array}$ \\
\hline TREATY +2 & $\begin{array}{c}53.412 \\
(191.38)\end{array}$ & $\begin{array}{c}-385.29 \# \\
(211.42)\end{array}$ & $\begin{array}{c}-59.452 \\
(81.804)\end{array}$ & $\begin{array}{c}49.228 \\
(46.249)\end{array}$ \\
\hline TREATY_+3 & $\begin{array}{c}303.57 \\
(258.83)\end{array}$ & $\begin{array}{c}-482.16 \# \\
(275.43)\end{array}$ & $\begin{array}{c}5.347 \\
(53.815)\end{array}$ & $\begin{array}{c}-88.825 \\
(62.869)\end{array}$ \\
\hline TREATY_+4 & $\begin{array}{c}617.73 * * \\
(145.92)\end{array}$ & $\begin{array}{c}-354.25 * \\
(161.73)\end{array}$ & $\begin{array}{c}-71.642 \\
(60.355)\end{array}$ & $\begin{array}{c}-69.752 \\
(37.319)\end{array}$ \\
\hline TREATY_+5 & $\begin{array}{c}586.54^{* *} \\
(199.24)\end{array}$ & $\begin{array}{c}-54.373 \\
(418.14)\end{array}$ & $\begin{array}{c}-56.688 \\
(75.327)\end{array}$ & $\begin{array}{c}-72.347 \\
(56.292)\end{array}$ \\
\hline R-squared & 0.560 & 0.246 & 0.336 & 0.168 \\
\hline F Test & $3.39 * *$ & $2.81 * *$ & $3.03^{* *}$ & $6.29 * *$ \\
\hline Sample Size & 337 & 464 & 640 & 1257 \\
\hline
\end{tabular}

NOTES: Robust standard errors are in parentheses, with **, *, and \# denoting statistical significance (two-tailed test) at the 1, 5, and 10 percent levels, respectively. 
Table 9: Treaty effects on U.S. OUTBOUND FDI STOCK by new treaty partner country.

\begin{tabular}{|l|c|c|c|}
\hline \hline $\begin{array}{l}\text { New treaty countries } \\
\text { treaty year) }\end{array}$ & $\begin{array}{c}\text { Estimated new treaty year } \\
\text { effects from first } \\
\text { differences specification }\end{array}$ & $\begin{array}{c}\text { FDI stock in treaty } \\
\text { year }\end{array}$ & $\begin{array}{c}\text { Average FDI stock } \\
\text { during sample }\end{array}$ \\
\hline CHINA (1985) & $-642.63^{* *}$ & 322.00 & 205.51 \\
\hline CYPRUS (1988) & -56.57 & 14.59 & 25.79 \\
\hline EGYPT (1981) & $-68.44^{*}$ & 1286.03 & 973.01 \\
\hline ICELAND (1976) & N.A. & 8.81 & 10.09 \\
\hline INDIA (1990) & $-569.98^{* *}$ & 312.11 & 547.97 \\
\hline INDONESIA (1989) & $-138.52^{* *}$ & 2425.40 & 2127.14 \\
\hline KOREA (1977) & 20.99 & 654.00 & 966.49 \\
\hline MOROCCO (1978) & $-83.83^{*}$ & 61.73 & 55.27 \\
\hline PHILIPPINES (1977) & $-115.81^{*}$ & 1385.82 & 1428.06 \\
\hline SPAIN (1991) & 6601.22 & 3269.46 \\
\hline
\end{tabular}

NOTES: Robust standard errors are in parentheses, with ** and *denoting statistical significance (twotailed test) at the 1 and 5 percent levels, respectively. 


\section{References}

Altshuler, Rosanne and T. Scott Newlon (1991), "The effects of U.S. tax policy on the income repatriation patterns of U.S. multinational corporations," NBER Discussion Paper, No. 571.

Altshuler, Rosanne, T. Scott Newlon, and William Randolph (1995), "Do repatriation taxes matter? Evidence from the tax returns of U.S. multinationals," Effects of Taxation on Multinational Corporations, eds. Martin Feldstein, James Hines, Jr. and R. Glenn Hubbard, University of Chicago Press, pp. 253-272.

Bali Online Corporation (1999) http://www.indo.com.

Blonigen, Bruce A. and Ronald B. Davies (2000), "The effects of bilateral tax treaties on U.S. FDI activity," NBER Working Paper, No. 7929.

Bond, Eric and Larry Samuelson (1989), "Strategic behaviour and the rules for international taxation of capital," Economic Journal, 99:1099-1111.

Brainard, S. Lael (1997), "An empirical assessment of the proximity-concentration trade-off between multinational sales and trade," American Economic Review, 87:4, pp. 520-544.

Bureau of Economic Analysis (1998), Detailed annual balance of payments and position estimates, Bureau of Economic Analysis International Data, Washington, D.C.

Carr, David, James R. Markusen, and Keith E. Maskus (2001), "Estimating the knowledge-capital model of the multinational enterprise," American Economic Review, 91:3, pp. 693-708.

Casson, Mark (1979), Alternatives to the Multinational Enterprise, Macmillan Press, London.

Caves, Richard E. (1993), Multinational Enterprise and Economic Analysis, Second Edition, Cambridge Surveys of Economic Literature, Cambridge Press, New York, New York.

Dagan, Tsilly (2000), "The tax treaties myth," New York University Journal of International Law and Politics, Summer 2000, pp. 939-996.

Diamond, Walter and Dorothy Diamond (1998), International Tax Treaties of All Nations, Ocean Publications, Dobbs Ferry, New York.

Doernberg, Richard (1997), International Taxation in a Nutshell, Third Edition, West Publishing Co., St. Paul, Minnesota.

Graham, Edward and Paul Krugman (1995), Foreign Direct Investment in the United States, Third Edition, Institute for International Economics, Washington, D.C..

Grubert, Harry, and John Mutti (1991), "Taxes, tariffs and transfer pricing in multinational corporate decision making," Review of Economics and Statistics, 73:2, pp. 285-293.

Hamada, Koichi (1966), "Strategic aspects of taxation on foreign investment income," Quarterly Journal of Economics, 80:361-75. 
Hartman, David (1985), "Tax policy and foreign direct investment," Journal of Public Economics, pp. 107-121.

Hines, James R. Jr. (1988), "Taxation and U.S. multinational investment," Tax Policy and the Economy, 2, ed. Lawrence Summers, MIT Press, pp. 33-61.

Hines, James R. Jr. (1992), “Credit and deferral as international investment incentives,"National Bureau of Economic Research Working Paper Series, No. 4191.

Hines, James R. and Kristen L. Willard (1992), ""Trick or treaty? Bargains and surprises in international tax agreements," Mimeo.

Janeba, Eckhard (1996), "Foreign direct investment under oligopoly: profit shifting or profit capturing?" Journal of Public Economics, 60: 423-445.

International Monetary Fund (2000), International Financial Statistics (CD-ROM version).

Markusen, James R. and Keith E. Maskus (1999a), "Multinational firms: reconciling theory and evidence," National Bureau of Economic Research Working Paper Series, No. 7163.

Markusen, James R. and Keith E. Maskus (1999b), "Discriminating among alternative theories of the multinational enterprise," National Bureau of Economic Research Working Paper Series, No. 7164.

Mutti, John and Harry Grubert (1996), "The significance of international tax rules for sourcing income: the relationship between income taxes and trade taxes," National Bureau of Economic Research Working Paper Series, No. 5526.

Nehru, Vikram, and Ashok Dhareshwar (1993), "A new database on physical capital stock: sources, methodology and results." Rivista de Analisis Economico, 8:1, pp. 37-59.

Organization for Economic Cooperation and Development (1989), Explanatory report on the convention on mutual administrative assistance in tax matters, OECD Committee on Fiscal Affairs, Paris.

Organization for Economic Cooperation and Development (1997), Model tax convention on income and on capital, OECD Committee on Fiscal Affairs, Paris.

Radaelli, Claudio M. (1997), The politics of corporate taxation in the European Union, Routledge Research in European Public Policy, London.

Sinn, Hans-Werner (1993), "Taxation and the birth of foreign subsidiaries," Trade, Welfare, and Economic Policies, Essays in Honor of Murray C. Kemp, ed. H Heberg and N. Long, University of Michigan Press, Ann Arbor.

Ramaswami, V. K. (1968), "International factor movement and the national advantage," Economica, 35:309-310.

Summers, Robert and Alan Heston (1991), "The Penn-World Table (Mark 5): an expanded set of international comparisons, 1950 - 1988," Quarterly Journal of Economics, 106:327-368.

White, Fredrick (1991), “The United States Perspective,” Tax Treaties and Local Taxes, International 
Fiscal Association, 16:15-24.

United Nations (1998), Bilateral Investment Treaties in the Mid-1990s, United Nations Conference on Trade and Development, New York.

United Nations (various years), World Investment Directory, United Nations, New York. (Volume I: Asia and the Pacific, 1992, Volume II: Central and Eastern Europe, 1992, Volume III: Developed Countries, 1993, Volume IV: Latin America and the Caribbean, 1994, Volume V: Africa, 1997, and Volume VI: West Asia, 1997) 


\section{Data Appendix}

\section{BEA Data on FDI Activity}

The FDI activity data reported by the BEA is subject to two types of censorship. First, if revealing the bilateral FDI activity would reveal the information of a single firm, only this information is reported due to confidentiality requirements. These observations were dropped. Second, if the FDI activity lies between $-\$ 500,000$ and $\$ 500,000$, only this information is given. These observations were set to zero. This censorship then left us with an unbalanced panel which covered different time periods for different activity measures. Outbound FDI stocks and outbound flows were at most available from 1966-1992 while their inbound counterparts were available from 1980-1992. Outbound sales data for 1983-1992 was obtained. Inbound sales covered the period 1984-1992. All measures are for nonfinancial institutions and can be found at http://www.bea.doc.gov/bea/di1.htm.

\section{Tax Treaties}

Information on tax data all came from the tax treaties themselves as reported by Diamond and Diamond (1998). Treaty effectiveness dates were based on when they actually became effective as opposed to when they were signed. If a treaty initially became effective before July 1 year, it was considered effective in that year. Otherwise, it was coded so that it was initially effective in the following year. Similar coding was used for treaty termination dates.

\section{Other Data}

Our GDP (both total and per capita) and trade openness measures are those from version 5.6 of the Penn-World Tables, which are available online at http://datacentre.chass.utoronto.ca:5680/pwt/. For a detail discussion of these measures, see Summers and Heston (1991).

Our education variable is the mean years of education for both males and females. This data is published by the World Bank and is discussed by Nehru and Dhareshwar (1993). The availability of this variable was the cause of the difference in the number of observations between the gravity and M-M specifications.

Distance was measure as the distance between capital cities as reported by the Bali Online Corporation. This distance calculator can be found at http://www.indo.com.

FDI openness was calculated as the U.S. dollar value of FDI stock divided by a country's GDP. FDI stock data were collected from United Nations' World Investment Directory published in various volumes over various years in the 1990s. Official statistics on FDI stock vary considerably and, in fact, are not available for many countries. In these cases FDI stock was estimated (both by the UN and us) by cumulating FDI flows from as early a year as possible. An appendix that details source and method of FDI stock data estimation for each country is available from the authors upon request. Nominal GDP figures were taken from the International Monetary Fund (2000).

\section{Descriptive Statistics of Data}

The countries in our cross-section, as well as the availability of education data, are reported in Table A1. Summary statistics for the entire data set are reported in Table A2.

Table A1: Countries used in at least one estimation specification. 


\begin{tabular}{|l|l|l|l|}
\hline Australia & Finland & Luxembourg & Rwanda \\
\hline Austria & France & Madagascar & Sierra Leone \\
\hline Bangladesh & Germany & Malawi & Singapore \\
\hline Belgium & Ghana & Malaysia & Spain \\
\hline Bolivia & Guatemala & Mauritius & Sri Lanka \\
\hline Brazil & Honduras & Mexico & Sweden \\
\hline Cameroon & Iceland & Morocco & Switzerland \\
\hline Canada & India & Mozambique & Thailand \\
\hline Chile & Indonesia & Netherlands & Tunisia \\
\hline China & Iran & New Zealand & Turkey \\
\hline Colombia & Ireland & Nigeria & Uganda \\
\hline Costa Rica & Israel & Norway & United Kingdom \\
\hline Cyprus & Italy & Pakistan & Uruguay \\
\hline Denmark & Ivory Coast & Panama & Venezuela \\
\hline Ecuador & Japan & Paraguay & Zimbabwe \\
\hline Egypt & Kenya & Peru & \\
\hline El Salvador & Korea & Phillippines & \\
\hline
\end{tabular}


Table A2: Descriptive statistics for entire data set.

\begin{tabular}{|c|c|c|c|c|c|c|}
\hline & Mean & Median & Std. Deviation & Minimum & Maximum & Observations \\
\hline Affiliate Sales-Out & 14054.18 & 1478.203 & 32013.72 & 0 & 179958.7 & 702 \\
\hline Affiliate Sales-In & 16149.98 & 712.3074 & 40105.73 & 0 & 267401.3 & 425 \\
\hline FDI Stock-out & 3282.979 & 402.8901 & 8381.612 & -1145.187 & 66888.71 & 1851 \\
\hline FDI Stock-in & 3385.721 & 23.61482 & 11173.48 & -119.4962 & 90554.57 & 811 \\
\hline RGDP & 120370.7 & 26717.76 & 235926.9 & 445.816 & 1873020 & 2075 \\
\hline RGDP-US & 3453398 & 3463851 & 680976.1 & 2391005 & 4575975 & 2106 \\
\hline SUMGDP & 3567807 & 3513959 & 755915.9 & 2391482 & 6448995 & 2075 \\
\hline GDPDIFSQ & $1.15 \mathrm{e}+13$ & $1.09 \mathrm{e}+13$ & $4.72 \mathrm{e}+12$ & $3.59 \mathrm{e}+12$ & $2.09 \mathrm{e}+13$ & 2075 \\
\hline D2SKDGDPD-In & -133908.8 & 0 & 1139478 & $-1.26 \mathrm{e}+07$ & 0 & 1736 \\
\hline D2SKDSUMG-In & 135530 & 0 & 1152893 & 0 & $1.27 \mathrm{e}+07$ & 1736 \\
\hline D1SKDSUMG-In & $2.00 \mathrm{e}+07$ & $1.97 \mathrm{e}+07$ & 9638812 & 0 & $4.61 \mathrm{e}+07$ & 1736 \\
\hline D2SKDGDPD-Out & $1.88 \mathrm{e}+07$ & $1.86 \mathrm{e}+07$ & 9249375 & 0 & $4.34 \mathrm{e}+07$ & 1736 \\
\hline D2SKDSUMG-Out & $2.00 \mathrm{e}+07$ & $1.97 \mathrm{e}+07$ & 9638812 & 0 & $4.61 \mathrm{e}+07$ & 1736 \\
\hline D1SKDSUMG-Out & 135530 & 0 & 115289. & 0 & $1.27 \mathrm{e}+07$ & 1736 \\
\hline DISTANCE & 5450.987 & 5258.5 & 2347.104 & 455 & 10163 & 2106 \\
\hline F_OPEN & 30983689 & .0574711 & .1581039 & -.2295737 & 3.419681 & 1676 \\
\hline OPEN-US & 16.73185 & 17.8 & 3.967776 & 9.86 & 21.9 & 2106 \\
\hline OPEN-FOREIGN & 62.51847 & 52.855 & 46.10281 & 4.99 & 423.41 & 2106 \\
\hline TREATY & .2962963 & 0 & .4567317 & 0 & 1 & 2106 \\
\hline
\end{tabular}

